\title{
La periodificación del Derecho Indiano en la obra de Alfonso García-Gallo
}

\section{The Periodification of the Indianous Law in Alfonso García-Gallo's Work}

\author{
Beatriz BERNAL GÓMEZ \\ Instituto de Investigaciones Jurídicas \\ UNAM. México \\ betiberg@yahoo.es
}

Recibido: 6 de noviembre de 2010

Aceptado: 10 de enero de 2011

\begin{abstract}
RESUMEN
La obra exitosa de mi maestro, Alfonso García-Gallo, ha tratado de múltiples temas indianos: he elegido dos artículos referidos a la evolución del derecho indiano, "Génesis y desarrollo del derecho indiano» y «Las etapas del desarrollo del Derecho Indiano», aunque también utilizaré otras obras, para tratar el tema de la periodificación de la historia del derecho en general y más concretamente en el Derecho Indiano. Para una visión más amplia de la cuestión he estudiado las obras de autores indianistas tanto en España como en América Latina.
\end{abstract}

PALABRAS CLAVE: Periodificación, obra de García-Gallo, Derecho Indiano, Recopilación de Leyes de Indias.

\begin{abstract}
The successful work of my teacher, Alfonso García-Gallo, has been relevant to multiple Indianous themes. I have selected two articles concerning the evolution of Indianous law, «Genesis and development of Indianous Law» and «Stages of the development of the Indianous Law», although I will also use other works, also addressing the issue of the Legal History periodification in general and more specifically of the Indianous Law. For a broader view of the issue, I have reviewed the works of indianists authors both from Spain and from Latin America.
\end{abstract}

KEYWORDS: Periodification, García-Gallo's work, Indianous Law, Recopilación de Leyes de Indias.

\section{RÉSUMÉ}

Le travail fructueux de mon professeur, Alfonso García-Gallo, a entamé plusieurs thèmes indiens. J'ai choisi deux articles concernant l'évolution du Droit Indien, " Genèse et évolution du droit Indien » et «Étapes du développement du Droit Indien », bien que je vais utiliser aussi d'autres œuvres. Abordant la question de la périodification de l'histoire du droit en général et plus particulièrement du Droit Indien. Pour avoir à obtenir une vision plus large de la question, j'ai étudié les œuvres d'autres auteurs indianistes tant en Espagne qu'en Amérique latine.

MOTS CLÉ : Périodification, œuvre de García-Gallo, Droit Indien, Recopilación de Leyes de Indias. 


\section{ZUSAMMENFASSUNG}

Das erfolgreiche Wirken von Alfonso García-Gallo, dem akademischen Lehrmeister des Artikelschreibers, hat vielfältige Themen des Derecho indiano berührt: so sind zwei Artikel zur Entstehung dieses Rechts zur nennen, «Genese und Entwicklung des derecho indiano» sowie «Die Entwicklungsschritte des derecho indiano», wobei auch andere Werke verwendet werden, um das Thema der Periodisierung ganz allgemein und ganz konkret im derecho indiano aufzuzeigen. Spanische wie lateinamerikanische Autoren der Indianistik kommen gleichermaßen zu Wort.

SCHLÜSSELWÖRTER: Periodisierung, Werk von García-Gallo, Derecho indiano, Sammlung der Leyes de Indias.

SUMARIO: 1. Prólogo. 2. Mis reflexiones en torno a la periodificación de la historia del derecho. 3. El desarrollo del derecho indiano en los textos de García-Gallo. 4. Epílogo.

\section{Prólogo}

Alfonso García-Gallo, fue sin lugar a dudas una de las figuras españolas más destacadas en el ámbito del estudio de la historia del derecho (en especial los derechos español e indiano) durante la segunda mitad del siglo pasado. Su obra, inmensa, hizo escuela y dejó gran impronta en quienes, como yo, tuvimos la suerte de ser sus discípulos directos. Es por eso que aplaudo la convocatoria de Cuadernos de Historia del Derecho (revista de la Facultad de Derecho de la Universidad Complutense de Madrid) al dedicarle el próximo número a quien fuera director del Departamento de Historia del Derecho y de las Instituciones de la Complutense durante casi cuarenta años, con motivo de conmemorarse cien años de su nacimiento.

Ahora bien, desde la muerte de García-Gallo en 1992, los estudios de historia del derecho han seguido avanzando. Por tal razón, aplaudo asimismo, la decisión que me hizo saber el profesor José Sánchez-Arcilla, también discípulo directo suyo, de elaborar trabajos que analicen la obra de don Alfonso desde un punto de vista crítico, con el fin de destacar que sobrevive de la misma y que requiere de actualización. A fin de cuentas, considero que esa es la labor que deben hacer los discípulos de un gran maestro, como sin duda lo fue don Alfonso. En igual sentido se expresa, poniendo manos a la obra en su espléndida monografía: "El tejido histórico del derecho indiano: Las ideas directivas de Alfonso García-Gallo", el destacado indianista e historiador del derecho argentino Víctor Tau Anzoátegui quien ha dicho de él y de su obra:

Toda disciplina necesita un orfebre mayor que de orientación y estímulo para su estudio, que establezca criterios, que persuada acerca de reglas que la deben regir, que traté de mostrar la globalidad de ese saber, es decir que recorra sus términos, fije sus límites, marque sus horizontes, precise su terminología, discuta y establezca sus bases metodológicas. Esta ímproba tarea es, por cierto, temporal, se agota en un tiempo determinado, necesita ser continuada, renovada, 
revitalizada. Dentro de los estudios históricos del Derecho indiano, fue sin duda García-Gallo quien cumplió esa misión durante cuatro décadas, desde los comienzos de los años 50 hasta fines de los $80 .{ }^{1}$

De la ingente obra de mi maestro, he elegido dos artículos referidos a la evolución del derecho indiano que en un momento dado fueron definitivos para mis estudios metodológicos. Estos son: "Génesis y desarrollo del derecho indiano", y "Las etapas del desarrollo del Derecho Indiano", ${ }^{3}$ síntesis del anterior. Aunque me referiré también a otras obras de don Alfonso donde deja claras sus ideas en torno a las orientaciones que han de seguirse en materia de periodificación de la historia del derecho en general, como su Manual de Historia del Derecho Español ${ }^{4}$ y "La evolución de la organización territorial de las Indias de 1492 a 1824".

Tendré en cuenta asimismo, además de mis trabajos sobre esta temática, ${ }^{6}$ otros relativos al desarrollo del derecho indiano, publicados por destacados indianistas en España y América Latina. Estos son, además del ya citado de Tau Anzoátegui, así como su Manual en coautoría con Eduardo Martiré7; los trabajos de Manuel Salvat Monguillot; ${ }^{8}$ Bernardino Bravo Lira; ${ }^{9}$ Silvio A. Zavala; ${ }^{10}$ Fernando Vázquéz Pando $;{ }^{11}$ y Antonio

\footnotetext{
${ }^{1}$ Ver la citada monografía de Tau Anzoátegui, Víctor, en Revista de Historia del Derecho, núm. 21, Instituto de Investigaciones de Historia del Derecho, Buenos Aires, 1993.

${ }^{2}$ Contenido en el apartado: "La Evolución del Derecho Indiano" en: Estudios de Historia del Derecho Indiano, Instituto Nacional de Estudios Jurídicos, Madrid, 1972.

${ }^{3}$ Contenido en: Los orígenes españoles de las instituciones americanas. Estudios de Derecho Indiano, Real Academia de Jurisprudencia y Legislación, Madrid, 1987.

${ }^{4}$ Tomo I, cap. I, $3^{\text {ra }}$ edición, Madrid, 1967.

${ }^{5}$ Primera edición en: Anuario Histórico Jurídico Ecuatoriano 5, Quito, 1980. Segunda Edición en: Los orígenes españoles de las instituciones americanas. Estudios de Derecho Indiano. Real Academia de Jurisprudencia y Legislación, Madrid, 1972

${ }^{6}$ Ver: Bernal Gómez, Beatriz: "Reflexiones en torno a la periodización de la historia del derecho", revista OMNIA, México, Año 2, Núm. 3, junio, 1986; “Cómo periodizar el derecho indiano”, Boletín Mexicano de Derecho Comparado, Nueva Serie, Año XIX, Núm.56, mayo-agosto 1986; "Los periodos en la historia del derecho romano", Estudios en homenaje al profesor Juan Iglesias, T.I, Seminario de Derecho Romano "Ursicino Álvares", Universidad Complutense de Madrid, 1988 y: "La Historia del Derecho Español. Notas en torno a su metodología, ubicación y periodización" en: Teoría de la Constitución. Estudios Jurídicos en Homenaje al Dr. Jorge Carpizo en Madrid, Editorial Porrúa, México, 2010 y “Derecho Indiano", Enciclopedia Jurídica Mexicana. Anuario, UNAM-Ed. Porrúa, México, 2005.

7 Eduardo Martié y Victor Tau Anzoátegui, Manual de historia de las instituciones argentinas, 5 a ed., Macchi, Buenos Aires, 1981.

8 "Problemática de la periodificación del derecho indiano", Revista Chilena de Historia del Derecho, Núm. 7, Editorial Jurídica de Chile, 1978.

9 "Oficio y oficina, dos etapas en la historia del Estado indiano", Revista Chilena de Historia del Derecho, Núm. 8, Editorial Jurídica de Chile, 1981.

10 "Algunas reflexiones sobre la historia del derecho patrio", Memoria del Colegio Nacional, Editorial del mismo, México, 1979 y Las instituciones jurídicas en la conquista de América, Porrúa, México, 1988. 11 "Derecho español en América, Derecho castellano vulgar y Derecho indiano (Una posible interpretación histórica)" y "En torno a la periodización y caracterización de la historia del derecho en México",
} 
Muro Orejón ${ }^{12}$, que dividen en periodos la historia jurídica, teniendo en cuenta, además del derecho, factores geográficos (Zavala) políticos (Muro y Vázquéz Pando), filosófico-ideológicos (Tau-Martiré), y político-dinásticos (Bravo Lira y Salvat).

Por último, tendré en cuenta las periodificaciones que varios de los maestros de nuestra disciplina han hecho en sus manuales de historia de los derechos español e indiano. ${ }^{13}$

\section{Mis reflexiones en torno a la periodificación de la historia del derecho}

En los varios trabajos que he escrito sobre cómo dividir en periodos la historia de los derechos romano, indiano y español, he opinado que toda periodificación es convencional y artificiosa, debido a que la humanidad no cambia en fecha fija, ni se interrumpe o fractura el proceso histórico a voluntad del historiador. ${ }^{14}$ En cada etapa van declinando ya las características del periodo que le precedió y se gestan o apuntan las del que indefectiblemente le sucederá en el tiempo. Así es el ciclo histórico. También, que toda periodificación presenta un alto grado de dificultad porque hay que encerrar y delimitar en una coordenada espacio-temporal determinada acontecimientos disímiles en cuanto a su intensidad, su devenir y su ritmo con el fin de entender y precisar con claridad lo que se está historiando.

Además, he sostenido que dividir en periodos la historia de cualquier derecho lleva consigo la tarea de caracterizar. Esto es, de extraer de cada etapa histórica sus denominadores comunes, aquellos que en cierta medida, son distintos a los que se encuentran en tiempos anteriores o posteriores. Es pues periodificar más caracterizar la labor que debe llevarse a cabo. La una sin la otra queda incompleta, coja. ${ }^{15}$ Por

Revista de la Facultad de Derecho de México, T. XXVI, núms. 101-102, enero-junio, 1976, y Memoria del II Congreso de Historia del Derecho Méxicano, México, 1980.

12 "Periodificación del derecho indiano", Revista Chilena de Historia del Derecho, Núm. 6, Editorial Jurídica de Chile, 1970

${ }^{13}$ Me refiero a los manuales de: José Antonio Escudero, Curso de historia del derecho. Fuentes e instituciones político administrativas, Madrid, 2003 (edición del autor); Francisco Tomás y Valiente, Ma-

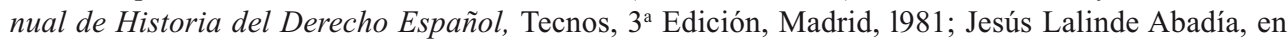
Derecho histórico español, Barcelona, Ariel, 1974; José María Ots Capdequí, Historia del derecho español en América y del derecho indiano, Aguilar, Madrid, 1969; Ismael Sánchez Bella, Alberto de la Hera y Carlos Díaz Rementería, Historia del Derecho Indiano, Mapfre, Madrid 1992; así como José Sánchez-Arcilla, "Una propuesta de periodificación de la Historia del Derecho Español”, en Estudios dedicados a la memoria del Profesor L.M. Diez de Salazar Fernández, vol. I, Bilbao, 1992, Servicio Editorial de la Universidad del País Vasco, pp. 33 a 63.

${ }^{14}$ Ver mis trabajos en nota 6. "La historia no es un continuum amorfo, lineal o indiviso. Pero tampoco actúa a saltos”, dice Francisco Tomás y Valiente, al elaborar la periodización de su estupendo Manual. Ob.cit., nota 13, p. 32.

${ }^{15}$ En sentido similar se expresa Fernando Vázquez Pando en la Introducción a su artículo: "En torno a la periodización de la historia del derecho mexicano" publicado en: Memoria del II Congreso de Historia del Derecho mexicano, UNAM, México, 1980. Ver también: Beatriz Bernal , "Las características del 
eso, periodificar no sólo es importante, es también necesario cuando se trata de la historia de cualquier derecho, en este caso el indiano. Hay que descubrir en el devenir histórico-jurídico las diversas etapas que lo integran con el fin de obtener una mejor comprensión de su secuencia. Fin que vale por su mismo y por la carga didáctica que representa.

Asimismo, he expuesto que para periodificar es menester, primero, precisar el objeto periodificable, después conceptualizarlo, definirlo, situarlo dentro de un marco sistemático e institucional, así como establecer sus límites de espacio y tiempo y fijar los criterios que se van a utilizar. Sólo así se podrá lograr una división en periodos que contenga, en la medida de lo posible, los cambios que se han producido en el desarrollo de la institución o sistema en cuestión. Además, para periodificar hay que tomar partido. Establecer que orientación se sigue al concebir la historia del derecho. Del concepto y orientación que tenga cada estudioso se derivará el método que emplee al elaborar su división en periodos.

Ahora bien, ¿cuál es el objeto de la historia del derecho y cuál la orientación que ha de seguirse para su estudio? Hoy en día hay plena unanimidad en cuanto a su objeto: estudiar el origen y las transformaciones del derecho a través del tiempo; esto es, su desarrollo. Sin embargo, siguiendo la doctrina de Alfonso García-Gallo, ${ }^{16}$ hay disparidad de criterios respecto a la finalidad que se persigue, disparidad que a su vez lleva consigo distintas orientaciones y métodos para su estudio. Estas orientaciones son la histórica y la jurídica. No hay que olvidar que la historia del derecho tiene una naturaleza bifronte: historia y derecho, inherentes ambas a esta disciplina. ${ }^{17}$

La orientación histórica concibe a la historia del derecho como una parte o complemento de la historia general, una rama de ella, como podrían serlo las historias económica, política, de las religiones y otras, aunque el método, permeado de una visión jurídica, difiera del propiamente histórico. Los que así estudian la historia del derecho dividen en etapas el objeto de conocimiento previamente delimitado y destacan en ellas la materia jurídica, en conexión con los periodos de la historia en general. En los panoramas generales de historia del derecho (Manuales) se usan con frecuencia dos métodos para explicar su desarrollo: el cronológico y el sincrónico. Conforme al primero de ellos la materia se divide por ramas, y a veces hasta por instituciones, y se expone el desarrollo histórico de cada una hasta el punto que se considera final de la evolución. Conforme al segundo, se distinguen los grandes periodos del proceso histórico y se estudian dentro de ellos, en mutua conexión, las diversas ramas e instituciones.

derecho indiano", Historia Mexicana, núm. 152, XXXVIII, IV, México, abril-junio, 1989; y Beatriz Bernal y José de Jesús Ledesma Uribe, Historia del derecho romano y de los derechos neorromanistas, capítulo III, "Periodización y método".

${ }^{16}$ Ver de Alfonso García-Gallo: "Las orientaciones actuales en el estudio de la historia del derecho", apartado III de las: "Cuestiones preliminares" de su Manual de historia del derecho español (T.I), ya citado. ${ }^{17}$ En cuanto a la naturaleza bifronte de la historia del derecho ver de Jesús Lalinde Abadía, "Los periodos históricos", ob. cit., cap. XI. 
La orientación jurídica centra su atención en el derecho. Pretende conocer éste en su pasado, desde sus orígenes hasta su actual regulación. No tiene como finalidad completar el panorama cultural de una época, sino estudiar el derecho en sí mismo, dentro, claro está, de su dimensión histórica. La historia del derecho se considera una ciencia, que obra auxiliada por el método histórico.

Ahora bien, dentro de esta orientación se manifiestan dos tendencias: la dogmática y la institucional. La primera, que prevaleció en el siglo XIX y en los inicios del XX, es la que siguen los romanistas y los iusprivatistas, y consiste en entender el derecho como un sistema conceptual cerrado y a priori, lo que los lleva a estudiar sus orígenes y desarrollo con los parámetros del sistema jurídico actual. La segunda, como su nombre lo indica (institucional) centra su atención en las instituciones de la vida social. A diferencia de la dogmática, plantea los problemas a que se enfrenta la sociedad, y estudia como han sido resueltos por el derecho. Para sus seguidores, el valor de la historia o "experiencia jurídica" radica en poder conocer las distintas soluciones aplicadas en el tiempo a un mismo problema, así como a apreciar su eficacia.

Los que siguen la corriente estrictamente histórica se ven en la necesidad de encasillar, en cada periodo de la historia general la evolución del derecho. Los que se alinean con la orientación dogmática, por el contrario, prescinden de las circunstancias de cada época histórica y se ocupan de los conceptos y normas por si mismos, como si tuvieran vida independiente. En el primero de los casos se corre el riesgo de atender a criterios meta-jurídicos -políticos, económicos, religiosos, etcétera- por encima de los que propiamente atañen al derecho. En el segundo se llega a prescindir totalmente de ellos. Se otorga al derecho un rango superior y se concentra la atención en el momento de su mayor madurez. Por último los seguidores de la orientación institucional consideran que cada institución tiene su evolución propia, y se abocan a la tarea de estudiarla en sus diferentes etapas.

¿Qué métodos se deben seguir cuando se pretende periodificar una institución o un sistema jurídico con características propias dentro de una coordenada espaciotemporal determinada? La respuesta es variable, depende del objeto de estudio. Si pretendemos estudiar una institución específica no hay duda que la orientación institucional es la adecuada, porque la institución por si misma determina su división en periodos. Y así con el apoyo del método dogmático puede partirse del momento de madurez o consolidación (por ejemplo, la encomienda indiana) desgajando los periodos de gestación y desenlace, previos y posteriores a su consolidación.

Ahora bien, sí lo que se pretende estudiar es la evolución de un sistema jurídico, creo necesario recurrir a la orientación histórica. En este caso debe hacerse hincapié en la evolución del derecho en el sistema estudiado y dividir en etapas o periodos cronológicos para observar su desarrollo y sus características. Cuando así se procede hay que tener en cuenta los criterios meta-jurídicos, sin duda determinantes del derecho como regulación de la vida en sociedad, pero sin permitir que estos criterios condicionen los momentos del cambio jurídico en sí mismo. Así al estudiar la evolu- 
ción del derecho en una coordenada espacio-temporal prefijada para observar su desarrollo y sus características, se atenderá al sistema de gobierno, al desarrollo económico, a los conflictos de carácter social, al sistema religioso y a otras variables, pero eligiendo siempre como fechas límites las de los cuerpos legislativos o jurisprudenciales que las reflejan. Esto es, los textos que fijaron o cambiaron el sistema jurídico entendido como un todo. De esta manera procedí al elaborar las periodificaciones de los derechos español, romano e indiano en mis trabajos ya citados. ${ }^{19} \mathrm{Y}$ con base a estas ideas procederé al analizar y valorar los textos de mi maestro.

\section{El desarrollo del derecho indiano en los textos de García-Gallo}

Siguiendo los presupuestos señalados en el acápite anterior, y por orden cronológico de aparición, procederé a analizar las divisiones en periodos del derecho indiano elaboradas por mi maestro en los dos artículos sobre la temática citados en el prólogo de este trabajo. Lo haré, poniendo en entrecomillado las obras y palabras del maestro.

"Génesis y desarrollo del Derecho Indiano", fue publicado inicialmente en $1964^{20}$ y reeditado en el primero de los volúmenes que recopilan los trabajos indianistas de García-Gallo, Estudios de Historia del Derecho Indiano, publicado en $1972 .{ }^{21} \mathrm{Se}$ trata de un espléndido ensayo sobre la evolución del derecho indiano desde sus orígenes en 1492 (Capitulaciones de Santa Fe) hasta su desaparición en el siglo XIX resultado del movimiento independentista de las colonias españolas continentales y de la sujeción de las islas no emancipadas (Cuba, Puerto Rico y Filipinas) a leyes especiales a que el autor hace referencia en el octavo y último de sus acápites: "La crisis del Derecho Indiano". Aunque García-Gallo no habla específicamente de etapas o periodos, este artículo contiene, sin duda, una periodificación de este derecho desde su nacimiento hasta su muerte; un derecho que como acertadamente dice: "ofrece al jurista y al sociólogo un tema digno de especial consideración porque puede ser estudiado en todo el proceso de su desarrollo" y porque a través de su estudio puede comprenderse: "en toda su complejidad las circunstancias y orientaciones que presidieron el desarrollo de la obra española en el Nuevo Mundo".

Luego de las muchas lecturas que he hecho de este artículo, he llegado a la conclusión de que García-Gallo divide en él la historia del derecho indiano en seis etapas o periodos, incluyendo en cada uno de ellos los principales acontecimientos que se sucedieron en los territorios conquistados, así como señalando las características del derecho en cada etapa. Estas son:

Primera etapa, a la que llama: "Los inicios del derecho indiano" (1492-1499). En ella destaca que dicho derecho nació antes de que se conocieran las Indias, esto es,

\footnotetext{
${ }^{19}$ Ver nota 6

${ }^{20}$ Primera edición en Atlántida. Revista del Pensamiento actual 2, 1964, pp. 339-359

${ }^{21}$ Ver nota 2. Esta edición es la que yo trabajé. "Génesis y desarrollo..." fue convertido después en casetes distribuidos por el autor a sus discípulos.
} 
antes de que se supiera qué países iba a regir este estatuto jurídico. Así, dice que: "tres meses y medio antes de que Colón zarpando de Palos inicie su viaje de descubrimiento y casi seis antes de que tocando la isla de Guanahaní este sea una realidad, los Reyes Católicos en las Capitulaciones concedidas a Colón en Santa Fe el 17 de abril de 1492 y en los documentos despachados en los días siguientes establecen las bases jurídicas del gobierno del Nuevo Mundo".

$Y$ añade que: "esta regulación previa no se establece en consideración a las condiciones propias del país en que ha de regir, que se desconocen, sino de acuerdo con los principios jurídicos medievales entonces imperantes y con la escasa experiencia hasta el momento obtenida en el trato con los pueblos paganos y salvajes; es decir, con los pobladores blancos de las Canarias o los negros de la costa africana". Y en efecto, esa era la experiencia de la Monarquía española hasta el momento. Por tal razón, todas las normas que los Reyes Católicos dictan y las instituciones que crean (virrey, adelantado, alcalde mayor, municipio) para el gobierno de las Indias se basan en el derecho castellano, "como no podía ser de otra manera". Pero el sistema fracasa porque la realidad del Nuevo Mundo es muy distinta a la de España y, por consiguiente, muy difícil de ser reglada por el derecho de Castilla, lo que dio lugar a una revisión de lo que se estaba haciendo en las Indias.

Segunda etapa a la que denomina: "La primera revisión" (1499-1511), en la que el fracaso de la empresa indiana: "supone un golpe de péndulo que lleva a una dirección completamente opuesta". Y aunque todavía sigue ajustándose a los derecho castellano y común (romano-canónico), ambos formados en los siglos medievales, las autoridades metropolitanas se dan cuenta que tienen que buscar soluciones jurídicas diferentes a las de la etapa anterior o adaptar las existentes a las peculiares circunstancias del Nuevo Mundo. Es entonces cuando los reyes empiezan a dictar normas especiales exclusivamente para él (todavía sólo las islas antillanas): "señalando primero las bases del nuevo sistema y precisándolas o corrigiéndolas luego, de un modo casuístico, a medida que las circunstancias lo requieren". Así comienza a desarrollarse un derecho especial para las Indias constituido por un conjunto de disposiciones que regulan los problemas de manera diferente al derecho de Castilla, aunque todavía inspirándose en los principios y normas del derecho común. Como bien dice GarcíaGallo en acertada frase: "El derecho indiano que ahora se forma de nuevo, nace con espíritu viejo". Y añade que: "como pocas veces en la historia, la elasticidad de un sistema jurídico se pone a prueba". Y posteriormente narra, con absoluta concisión, las nuevas instituciones que crea la Corona para gobernar las Indias (Casa de Contratación de Sevilla, Audiencia, Gobernación, Patronato Indiano) así como las medidas que se adoptan para solucionar los problemas de la falta de producción de los territorios indianos (repartimiento de indios) Vemos en esta etapa la primera caracterización que el autor hace del derecho indiano: especialidad y casuismo.

Tercera etapa que el autor titula: "El planteamiento integral del problema jurídico indiano" (1511-1513): “Apenas transcurridos 12 años de la adopción de la nueva po- 
lítica un hecho en si vulgar e intrascendente va a conmover hasta lo más profundo la conciencia de los gobernantes de la Península". Este hecho fue el sermón de fray Antón de Montesinos en la capilla de los dominicos de la isla Española, denunciando el mal trato a los indios (14 de diciembre de 1511), el que provocó, otra vez, una revisión total de la política indiana. Desde mi punto de vista, el acontecimiento ni fue "vulgar", ni mucho menos "intrascendente", pues resultó ser el punto de partida de la relación que en el futuro, aunque sólo fuera en el papel, habrían de tener los conquistadores con los conquistados, mucho mayor en número, además de ser los habitantes autóctonos de las islas y en cuyos hombros recaería la producción futura de las Indias. Fue por eso, creo, por lo que Fernando el Católico convocó una Junta de teólogos y juristas para revisar, no sólo el comportamiento que tenían los españoles con los indios y las leyes que regulaban su relación, sino también la legitimidad del poder que tenía la Corona española sobre las Indias y los indios. Y esa Junta reunida en Burgos en 1512 (que da lugar a las leyes del mismo lugar y año): “enfoca y enjuicia la cuestión conforme a los principios indiscutidos de la teología y el derecho vigentes. Mas, siendo estos los mismos que veinte años antes, la conclusión a la que llega no puede ser otra a la que en 1492 había prevalecido: el descubrimiento de las Indias y la concesión pontificia [Bulas alejandrinas] de estas a los reyes de España, son títulos suficientes que legitiman su poder en ellas". Pero algunos indios se rebelaron y no aceptaron la dominación de los españoles, y estos, con el fin de legitimar la guerra que van a hacerles, inventaron la absurda figura jurídica del "requerimiento"-creada por el jurista-teólogo Juan López de Palacios Rubio-para someterlos, y trasplantaron a América la institución de la "encomienda", a través de la cual se aseguraron la mano de obra gratuita (semiesclavitud) con el compromiso del encomendero de cuidar de los indios e instruirlos en la religión y en el trabajo. Como bien dice el autor: "la Junta de Burgos viene más a consolidar el sistema anterior que a introducir cambios sustanciales a la política indiana". En esta etapa, además, se intensifica la conquista, ya encargada a la empresa privada a través de capitulaciones (aunque todavía la Corona organiza expediciones de conquista como las de Pedrarias Dávila al Darién y la de Magallanes en busca de la ruta a la India) y en unos treinta años se integraron a la Monarquía la Florida, México, toda América central, Venezuela, Colombia, Ecuador, Perú, parte de Chile y el Río de la Plata y se recuperaron y crearon instituciones como el Virreinato (suspendido temporalmente después de Colón) y el Consejo Real de las Indias. En resumen, la Junta y las Leyes de Burgos no introdujeron cambios sustanciales en la política indiana, pero sí removieron problemas no solucionados en cuanto a la relación entre conquistadores y conquistados y despertaron inquietudes que condujeron a una nueva etapa que García-Gallo, parafraseando la clásica obra de Lewis Hanke ${ }^{22}$ denomina: "La lucha por un derecho justo", complementada por el siguiente acápite: "El derecho indiano frente al derecho natural".

${ }^{22}$ Lewis Hanke, La lucha por la justicia en la conquista de América, (traducción de Ramón Iglesia) Ed. Suramericana, Buenos Aires, 1949. 
Cuarta etapa (1513-1566): “A partir de 1513, la política que se sigue en Indias se desarrolla bajo el signo del más agudo criticismo", opina el autor. Y opina bien. Es la etapa en que se analiza y polemiza sobre la legitimidad del dominio que tiene los reyes de España sobre las Indias y sus habitantes (polémica sobre los Justos Títulos), sobre los derechos de los españoles establecidos en las Indias, sobre la libertad, el tratamiento, la evangelización y la condición jurídica de los indios, sobre el régimen de la encomienda, sobre la organización político-administrativa de los nuevos territorios, y "sobre todo cuanto puede ser objeto de discusión". Y se hace a través de informes (relaciones, memoriales, cartas, crónicas y otros) enviados al Rey por todo tipo de autores (conquistadores, pobladores, funcionarios reales, religiosos, todos menos los indios) que interactúan en diferentes zonas geográficas con los naturales del lugar (naturales que constituyen un mosaico de pueblos y de grados de cultura) y que tienen distintas actitudes e intereses ante el mundo americano. Los conquistadores pretenden riqueza mediante la obtención de una retribución real por sus conquistas; los pobladores también, los funcionarios reales de más alto rango pretenden cumplir con sus funciones (los de más bajo rango enriquecerse), los religiosos, sobre todo los del clero regular, evangelizar cumpliendo con el mandato de las Bulas alejandrinas. Total, que al rey y al Consejo le llegan opiniones diversas, confusas y contradictorias de cómo deben gobernarse las Indias. Y aunque ambos se esforzaron por coordinar todos esos interesen y ordenar el Nuevo Mundo conforme a Derecho no lo lograron. Entonces, ¿que hicieron? Pues bien, cuando pudieron adaptar el derecho castellano lo adaptaron, pero cuando las condiciones eran diferentes y no bastaba la mera adaptación crearon un derecho nuevo: el derecho indiano, que además de especial y casuístico va a ser vacilante, ocasional, indeciso (de ensayo y error) que: "va poniendo parches allá donde la fuerza de la realidad acusa fisuras en el ordenamiento vigente". Además, como no hubo un plan general para el gobierno de las Indias, estas nuevas leyes no tuvieron vigencia en todas las Indias, sino sólo en la provincia para la que fueron dictadas, aunque podían repetirse para otros territorios. Esto hizo que la legislación aumentara excesivamente y que naciera otra característica del derecho indiano: ser prolífico. Ahora bien, el Consejo de Indias, poco a poco, va acumulando experiencia en ciertos campos y se va formando un criterio y un plan general superando en parte el casuismo a través de la formulación de pequeños códigos sobre una materia llamados Ordenanzas, que regulan los diferentes aspectos de una determinada institución.

Así, en este periodo, se dictaron, con respecto a los indios, las Ordenanzas de Burgos completadas en Valladolid en 1513 y revisadas en Zaragoza en 1518; las Ordenanzas de Descubrimientos de 1526, que se reproducen en cada nueva capitulación que se otorga al descubridor; las Ordenanzas de la Casa de Contratación que se dictan en 1531 y se repiten hasta 1539; las Ordenanzas de Audiencias de la Española y México, en 1528 y 1530 y las Ordenanzas para Corregidores y Oficiales Reales de Hacienda de la Nueva España en 1530. Sin embargo, "Esta copiosa legislación con 
la que el rey y el Consejos de Indias desde la Península tratan de establecer un orden [...] no siempre logra su efecto y aun crea problemas. Unas veces las leyes [...] resultan inadecuadas, porque se aplica en un lugar la norma que se ha mostrado justa y eficaz en otro, sin caer en cuenta de que las condiciones de aquel y de este son distintas; o las leyes se revelan imposibles de cumplir, contraproducentes o insuficientes" Asimismo, "otras lesionan intereses y provocan resistencia, o simplemente no se cumplen, o los interesados aplican soluciones para resolver los conflictos que son contrarias a la legislación". Eso no es de extrañar si se tiene en cuenta la lejanía de la Metrópoli y el caos legislativo producto de la excesiva proliferación de leyes, así como la imposibilidad del conocimiento de ellas, lo que tiene como consecuencia la creación de un derecho consuetudinario que, si bien inspirado en el viejo derecho de Castilla, se adapta mejor a la realidad indiana.

A pesar de estos avances, los conflictos siguieron en las décadas posteriores. Se volvió a polemizar sobre la legitimidad del dominio de los reyes sobre las Indias, sobre la libertad y condición jurídica del indio y sobre el régimen de encomienda que había sustituido al repartimiento. Sólo que ahora, frente a la perspectiva de los derechos medieval castellano y común europeo, los frailes dominicos, con Bartolomé de las Casas a la cabeza, opusieron el derecho natural que, conforme a la doctrina tomista, concedía a todos los hombres, aunque fueran infieles o "salvajes", la plena capacidad y los mismos derechos que detentaban los cristianos "civilizados" de Europa. Resultado de ello fue la concepción lascasiana de que los indios debían ser libres y gozar de todos los derechos, porque no estaban al amparo del derecho medieval sino del natural. La apasionada defensa de Las Casas produjo tanto escándalo que en 1542 las Cortes de Valladolid suplicaron a Carlos V que remediara las crueldades cometidas en las Indias y el emperador mismo llegó a pesar en devolver parte de sus territorios a sus antiguos dueños. En esta atmósfera de crítica y libertad de expresión, surgió la voz equilibrada y mediadora de Francisco de Vitoria, el más destacado de los teólogos-juristas de la Segunda Escolástica, quien dio un nuevo planteamiento al problema indiano en sus famosas Relectiones de Indiis y Relectiones de Iure belli pronunciadas ambas en 1539, en la Universidad de Salamanca. Vitoria desechó la mayoría de los títulos esgrimidos hasta entonces para legitimar la conquista, pero formuló otros para justificar el dominio castellano en Indias, entre ellos: la sociedad y la comunidad naturales entre los hombres basada en el ius gentium, poniendo con ello las bases del derecho internacional público, así como la sumisión libre y voluntaria de los indios a los reyes de Castilla. Asimismo, aunque rechazó la guerra contra los indios infieles, defendió los derechos de los ya cristianizados. Tuvo el mérito, dijo atinadamente Silvio Zavala: "de encontrar un principio que sirviera de unión entre los mundos europeo y americano"23. Después del planteamiento de Vitoria, Carlos V pidió revisar otra vez la política de gobierno para las Indias y cons-

\footnotetext{
${ }^{23}$ Silvio A. Zavala, Las instituciones jurídicas ..., op. cit., ver nota 10.
} 
tituyó otra Junta que culminó con la promulgación en Barcelona (1542) de las Leyes Nuevas. En ellas se suprimió el carácter hereditario de la encomienda, se proclamó y reconoció otra vez la libertad de los indios, así como la dualidad entre las repúblicas de españoles y de indios y se reguló otra forma de hacer los nuevos descubrimientos y poblaciones. Su aplicación, por la supresión de la encomienda por varias vidas, generó graves problemas con los colonizadores, sobre todo en el Perú por lo que tuvieron que ser derogados varios de sus capítulos. Sin embargo, las Leyes Nuevas quedaron como texto fundamental del gobierno de las Indias y sirvieron de punto de partida para muchas reformas posteriores.

Aunque resuelto el problema de la legitimidad del poder que tenían los reyes españoles sobre las Indias, quedaba todavía por resolver el problema de la legitimidad del dominio sobre los indios. Las Bulas Alejandrinas sólo habían concedido a los reyes el derecho sobre los territorios y no sobre los pueblos que los ocupaban. Para enfrentarse a esta problema, Carlos V convocó a otra Junta de teólogos y juristas en Valladolid (1550) donde se oyó a los protagonistas de ella: Juan Ginés de Sepúlveda, ${ }^{24}$ quien sostenía que los indios, por su rudeza natural y limitada inteligencia, su idolatría y su canibalismo, debían ser sometidos a los españoles, por lo cual, para su cristianización se les podría hacer la guerra; y Bartolomé de las Casas $^{25}$, quien tenía una posición diametralmente opuesta. Para él, los indios, inteligentes y virtuosos, eran libres por derecho natural. Por consiguiente, sólo se les podría evangelizar por vía pacífica, de lo que se derivaba que las guerras hechas a los indígenas eran injustas. Aunque la Junta de Valladolid no resolvió el problema, según el autor, al no tomar una decisión colectiva, ambos rivales (Las Casas y Sepúlveda), se creyeron vencedores en la contienda, y fue el punto de partida que llevaría a una solución décadas después, durante el gobierno de Felipe II, con la promulgación de las Ordenanzas de Nuevos Descubrimientos, Pacificación y Poblaciones de 1573, que quedaron contenidas en el libro VI de la Recopilación de Leyes de los Reynos de las Indias de 1680. Aunque dichas Ordenanzas no pretendieron hacer ninguna declaración de principios, estos existían y se traslucían a través de sus disposiciones, Ellos fueron: 1) el reconocimiento del señorío y jurisdicción universal que los reyes tenían sobre el territorio de las Indias, nacido de la concesión pontificia y consolidado por el descubrimiento y la ocupación de ellas; y 2) la declaración de que esos títulos no conferían al rey derecho alguno sobre los indios, porque éstos eran libres e independientes por derecho natural, aunque vivieran en un territorio que jurídicamente pertenecía a los reyes de Castilla. Había ganado Bartolomé de las Casas, aunque García-Gallo hable de "tablas". Otra cosa es que el derecho natural se cumpliera. En las Indias hubo siempre un divorcio entre la ley y la realidad, sobre todo en materia del tratamiento de los indios, que el autor nunca señala.

\footnotetext{
${ }^{24}$ En sus dos famosas obras: Democrater Alter y Democrater Secundus.

${ }^{25}$ En sus obras: Remedios para la reformación de las Indias y Treinta proposiciones muy jurídicas.
} 
Quinta Etapa (1566-1680): Este periodo que el autor denomina: "La consolidación del Derecho Indiano" abarca desde las reformas "ovandinas" (1566 y 1575) hasta la promulgación de la Recopilación de Leyes de Indias en 1680. En él, Juan de Ovando, quien fue nombrado por el rey Visitador del Consejo de Indias entre 1556 y 1561, estableció las causas del fracaso de la empresa indiana. Estas eran: 1) La desinformación o información defectuosa que tenía la Corona de lo que pasaba en Indias, debido, como ya he dicho, a la lejanía de los territorios y a los diferentes intereses de los informantes. No pensaban ni informaban lo mismo los conquistadores y encomenderos interesados en obtener riquezas, que los clérigos preocupados por cristianizar y defender a los indígenas o los oficiales reales empeñados en hacer cumplir con rigor las leyes que provenían de la Metrópoli. Es más, en muchos casos sus informaciones eran contradictorias; 2) La variedad y extensión de los territorios descubiertos y conquistados que, además, se encontraban en diversos estadios de civilización y desarrollo; desde los caníbales y los indígenas recolectores de las islas del Caribe y los indios rebeldes de la Araucaria, hasta los grandes imperios de los aztecas y los incas; 3) La ineficiencia de los oficiales que se enviaban a las Indias, totalmente desconocedores de la vida americana y elegidos más por influencias o premios de conquista que por su capacidad y 4) La excesiva legislación indiana, tanto metropolitana como criolla, y el desconocimiento que las autoridades y los aplicadores del derecho (jueces y letrados) tenían de ella.

Una vez señaladas las causas del fracaso de la empresa indiana, Juan de Ovando se abocó a ponerle remedio. Para la incapacidad de los funcionarios, dicho remedio consistió en promover la carrera indiana (cursus indiarum). Si bien Ovando no había estado nunca en las Indias, estaba familiarizado con los avatares de Nuevo Mundo, pues era natural de Cáceres, había sido alumno de Vitoria en Salamanca y sobrino nieto del exgobernador de la Española, Nicolás de Ovando; para el desconocimiento de las Indias el remedio fue obtener mayor y mejor información a través de un amplísimo cuestionario que envió a las autoridades delegadas en Indias para que informaran detalladamente sobre sus respectivos lugares y ciudades. También mandó requerir la opinión de los naturales. Así, por primera vez se les preguntó a los indígenas que pensaban sobre la forma en que se les estaba gobernando. Esto se llevó a cabo a través de un cuestionario que ha pasado a la historia con el nombre de: Cuestionario de Felipe II. Asimismo, se empezó a respetar a la elite indígena. Como dice el autor: "La autonomía de la república de los indios se manifiesta tanto en el respeto que desde ahora se guarda a sus caciques o señores naturales, como en el reconocimiento expreso de su propio derecho en tanto no contradiga las leyes naturales o las dictadas por los reyes de España". ${ }^{26}$ Como resultado de ello, en materia de tributos, los pueblos de indios se rigieron por su propio sistema jurídico, muy adelantado en los imperios azteca e inca. Esto obligó a algunos magistrados españoles a conocer las

\footnotetext{
${ }^{26}$ Que quedó contenida en Recopilación de Leyes de los Reynos de las Indias, II.I.2.
} 
costumbres jurídicas indígenas, como fueron los casos de Juan de Santillán en el Perú y Alonso de Zorita en la Nueva España. Y, por último, para el desconocimiento de la legislación indiana por jueces y funcionarios, Ovando comenzó, promovió e impulsó la realización de una recopilación (Código de Ovando) que no llegó a promulgarse. ${ }^{27}$

Por tales, razones, Ovando, en 1571 fue nombrado presidente del Consejo de Indias con poderes excepcionales y promulgó unas detalladas Ordenanzas: los Estatutos del Consejo Real de Indias, en 1571, entresacas de su proyecto de Código, y en 1573 unas ordenanzas sobre descripciones de cada una de las provincias americanas: las Instrucciones de Descripciones que dotó al Consejo de una información precisa de las mismas y que evitó en adelante legislar sin conocer las Indias. Además, la obra legislativa de Ovando, aparte de las Ordenanzas del Consejo y de Descripciones se completa con las Ordenanzas de Regio Patronato Indiano (1574) y las de nuevos descubrimiento y poblaciones (1573) citada en la etapa anterior. La muerte de Ovando en 1575 dejó interrumpida una labor que: "por lo que de ella conocemos, de concluirse, hubiera constituido la más perfecta ordenación del sistema indiano".

En resumen, gracias a Ovando, el derecho indiano alcanzó su madurez y se mostró como un sistema jurídico consolidado que dio lugar a una legislación más precisa ${ }^{28}$ y a una amplia y rica literatura jurídica. ${ }^{29} \mathrm{Y}$ todo esto se debió a que, a través de las minuciosas descripciones que se recibían en la Metrópoli, se pudieron conocer mejor las Indias; también a que se enviaron a ella y al Consejo los mejores funcionarios familiarizados con problemas americanos; y a que se hicieron compilaciones, tanto en España como en América de las leyes que se encontraban en el Consejo y en las audiencias indianas, con lo que se facilitó a todos el conocimiento de la legislación; aunque la recopilación que se comenzó a elaborar a partir de 1603 en la Metrópoli y que tuvo sus antecedentes en México y Perú, ${ }^{30}$ no llegaría a promulgarse hasta 1680.

\footnotetext{
${ }^{27}$ Este Código comenzó con la elaboración de la Copulata de Leyes y Provisiones, un extracto de todas las disposiciones legislativas que había en el Consejo de Indias que Ovando mandó elaborar como guía para su Código. Este estaría dividido en cuatro libros y títulos organizados por materias. Ovando elaboró los dos primeros libros sobre la gobernación espiritual y temporal de las Indias y parece que también los dos últimos sobre la república de los españoles y de los indios. Por dificultades con el Vaticano que tenía que dar el placet al libro primero (gobernación espiritual) ninguno de los libros se imprimió ni publicó, razón por la cual, su contenido se promulgó y publicó en forma de las Ordenanzas ya citadas en el texto.

${ }^{28}$ Que quedó contenida en el Cedulario de Diego de Encinas de 1596.

${ }^{29}$ La obra más significativa de esta "Edad de oro" de la literatura jurídica indiana fue la Política Indiana (1647) de Juan de Solórzano y Pereira, oidor de la Audiencia de Lima y más tarde consejero de Indias. ${ }^{30}$ Los primeros intentos de recopilar el derecho indiano se llevaron a cabo en México. Una Real cédula de 1533, dirigida a las audiencias de México y Santo Domingo, ordenó a sus oidores recoger todas las ordenanzas, provisiones y cédulas que se habían dictado para ellas y enviar copias al Consejo de Indias. Años después el virrey de Nueva España, Luis de Velasco, en 1552, recopiló las disposiciones legislativas enviadas a su virreinato. Le siguieron Antonio de Maldonado y Vasco de Puga, ambos fiscales de la Audiencia de México, quienes elaboraron un Repertorio de Cédulas que no llegó a terminarse, el primero y el Cedulario de la Nueva España, el segundo, obra de gran relevancia para el derecho in-
} 
Sexta Etapa. (1680-1776): Con el nombre de: "El reformismo borbónico" afronta García-Gallo su sexta y última etapa. "A los largo del siglo XVIII -dice- se opera un nuevo e importante cambio en el Derecho Indiano". Y es cierto, porque en ese siglo se instalaron los Borbones en España, lo que trajo como consecuencia cambios, no sólo dinásticos, sino también ideológicos y políticos que se reflejaron en el derecho. Educados cultural y jurídicamente a la francesa, los reyes y los hombres de gobierno de la casa de Borbón, que eran absolutistas, racionalistas e ilustrados, dieron paso a múltiples reformas, tanto en el ámbito político-administrativo, como en los ámbitos económico y jurídico; reformas que no se implementaron de inmediato, pero que "poco a poco van cambiando la actitud del gobierno español respecto a América" y se consolidaron a lo largo del siglo. "Ahora el rey, más que un administrador es el amo y señor de la Monarquía, lo que hace que se desvinculen las Indias de ésta y puedan ser enajenadas o divididas". Así, mientras algunas se enajenaron, otras se convirtieron en nuevos virreinatos: los de Nueva Granada (1717) y del Río de la Plata (1776). Y se pasó del régimen de oficios reales, característico de la dinastía de los Austrias, que otorgaba una cierta independencia a los oficiales reales con relación a su superior inmediato, al régimen de oficinas, ${ }^{31}$ que se basó en un orden jerárquico racional que fue en escalera desde el último de los funcionarios hasta el rey. Y se crearon las intendencias ${ }^{32}$ (primero en Cuba, después en Buenos Aires, y por último en todos los territorios) a la manera francesa, con sus cuatro ramas de hacienda, gobierno, justicia y guerra, y también las Secretarías de Estado que sustituyeron al Consejo de Indias, que aunque perduró se quedó sin funciones. En este nuevo orden, la máxima autoridad indiana será el Secretario de Estado de los Asuntos de Ultramar.

En el ámbito económico, bajo la influencia del mercantilismo se trató de desarrollar (y se logró) la riqueza del país, a través de los propios órganos del Estado. Además, se descentralizó el comercio y se suprimió el monopolio que hacía que los puertos americanos sólo pudieran comerciar con la Metrópoli, sin que pudieran hacerlo entre sí. El tránsito del proteccionismo económico en el periodo de los Austrias, al liberalismo de la etapa de los Borbones, dio lugar a un auge económico en las colonias americanas que influyó grandemente en sus movimientos independentistas.

En cuanto al ámbito jurídico, el derecho indiano metropolitano, "tiende a parecerse otra vez al castellano", y generó una copiosa legislación que emanó: "no sólo del Consejo de Indias sino también de los secretarios de Estado [y] que va derogando las

diano que se publicó en 1563 y que fue continuada por otro oidor de la Audiencia de México, Alonso de Zorita, quien hizo un Cedulario que nunca obtuvo el placet real. El virreinato del Perú entró más tarde al proceso recopilador. La compilación más antigua fue la mandada hacer por el virrey Antonio de Mendoza en 1552. Más tarde el virrey Antonio de Toledo en 1569 comenzó a recopilar las leyes, pero fue interrumpido por Juan de Ovando, entonces presidente del Consejo de Indias, quien le ordenó suspender sus trabajos, pues se empezaba la labor recopiladora en España.

${ }^{31}$ Ver Bernardino Bravo Lira: Oficio y oficina. Dos etapas..., citado en la nota 8

${ }^{32}$ Ver Ricardo Rees Jones, El despotismo ilustrado y los intendentes de la Nueva España, México, 1979. 
viejas leyes recogidas de la Recopilación de 1680, cuyo contenido, en buena parte, queda sin vigor, lo que no impide que todavía se reimprima tres veces sin la menor alteración". Sin embargo, el derecho indiano criollo se mantuvo vivo. Ahora bien, la obsolencia del también llamado Código Santo dio lugar a la utilización de nuevas colecciones de leyes borbónicas y de notas y comentarios al texto del mismo con el objeto de actualizarlo, hasta que en la segunda mitad del siglo XVIII se mandó a hacer otra recopilación: el Nuevo Código de Indias,(1776) que nunca llegó a promulgarse completo.

Sólo me resta añadir que el movimiento independentista americano de la América continental que se gestó, desarrolló y triunfó en las primeras décadas del siglo XIX dió la puntilla al derecho indiano. Las nacientes repúblicas fueron creando su propio derecho a lo largo del siglo XIX. Solamente la América insular (Cuba, Puerto Rico y las Filipinas) se mantuvieron atadas a España y a su derecho, aunque con leyes especiales. El derecho indiano como un todo, había hecho crisis. Se había cumplido un ciclo histórico.

El otro ensayo de García-Gallo, "Las etapas del desarrollo del derecho indiano"33 fue publicada por primera vez en Costa Rica ${ }^{34}$ con motivo de la celebración del tercer centenario de la publicación de la Recopilación de Leyes de Indias en 1681. Por tal razón, el maestro comienza su trabajo reflexionando sobre la imposibilidad de elaborar un desarrollo cabal del sistema jurídico indiano basándose sólo en dicha Recopilación, sin tener en cuenta otros textos legales y doctrinales que llevan a la compresión del sistema jurídico indiano ${ }^{35}$ "La consideración histórico-jurídica del derecho ha de compaginar y conciliar el estudio del sistema y de su evolución [...] Es esta una dificultad que se presenta en todos y cada uno de los estudios históricojurídicos que no se limite a contemplar una institución en un momento de su pasado, sin atender a sus orígenes o antecedentes ni a su suerte posterior". No debe verse la historia del derecho, añado yo, en forma estática, como en una fotografía; sino como un proceso, como una película que va de los créditos al anuncio de fin. Sobre todo, ya se ha dicho, cuando en un sistema jurídico como el que nos ocupa, se tiene una fecha precisa de nacimiento: Capitulaciones de Santa Fe (17 de abril de 1492)) y varias fechas de muerte: los triunfos de los movimientos independentistas de la América continental en las primeras décadas del siglo XIX. Y aunque García-Gallo estima que: "el ritmo de la evolución de esta regulación difiere de unas instituciones a otras, de tal modo que resulta difícil dividir la historia jurídica indiana en épocas, como es frecuente en otros estudios históricos [...] es posible destacar hechos que por su sig-

\footnotetext{
${ }^{33}$ Ver nota 3.

${ }^{34}$ En: Memoria del Simposio Hispanoamericano sobre las leyes de Indias (San José de Costa Rica, 2730 de octubre de 1981) Instituto Constarricense de Cultura Hispánica-Instituto de Cooperación Iberoamericana, San José, 1984.

${ }^{35}$ En esto sigue la tendencia establecida por Rafael Altamira Crevea, Técnica de la investigación en la historia del derecho indiano, José Porrúa e hijos, México, 1939.
} 
nificación y trascendencia marcan hitos en el largo proceso de la formación del derecho indiano".

Y hecha esta última reflexión, el maestro se aboca a hacer una periodificación señalando las fechas de inicio y final de cada periodo, a los cuales, por primera vez, les llama etapas. La primera etapa, al igual que en "Génesis y desarrollo, abarca de 1492 a 1499, fecha de la suspensión de Cristóbal Colón en el ejercicio de sus cargos americanos, de la rectificación de la política descubridora y del establecimiento de un nuevo sistema indiano. Lo mismo sucede con la segunda que se extiende de 1499 a 1512 que culmina con el sermón de Montesinos, la Junta de Burgos y la promulgación de las Leyes del mismo nombre. La tercera (1512-1566) es una etapa revisionista que dura más de cuatro décadas en la que se plantean los más importantes problemas de la política indiana: la legitimidad de los títulos que tiene la Corona española para detentar la soberanía sobre las Indias, y como consecuencia, la posesión territorial de ella y el dominio sobre sus habitantes. Se cuestiona también la libertad (otorgada por Isabel la Católica desde los inicios de la conquista y ratificada después en su famoso Codicilo), el tratamiento y la condición jurídica que debía darse a los indígenas o naturales y el derecho a hacerles o no una "guerra justa". En ella, a diferencia de las dos anteriores en que se pretende gobernar con base al derecho medieval común y castellano, se desarrolla un derecho especial para las Indias que tiene como características, además del casuismo la especialidad, el ser un derecho prolífico, vacilante, indeciso, de ensayo y error.

La cuarta comienza en 1566 cuando el bachiller Luis Sánchez entrega un Memorial al presidente del Consejo de Indias denunciando la despoblación y destrucción de las Indias, lo que provoca que Felipe II encargue al Lcdo. Juan de Ovando la visita e inspección a dicho Consejo, hasta que, en 1680) en épocas del último rey Austria (Carlos II, el Hechizado), se promulga la Recopilación de Leyes de Indias. Es una etapa larga, de organización de la vida indiana en la que su derecho se vislumbra como un sistema propio, lejos del derecho especial de la etapa anterior, y cuando al derecho castellano se le da categoría de derecho supletorio ${ }^{36}$. Por eso, en el momento en que Juan de Solórzano publica su Política Indiana "no se reduce a recoger y analizar las leyes dictadas para el Nuevo Mundo sino que construye un sistema, afirmando sus fundamentos filosóficos y doctrinales, caracterizando las instituciones y analizándolas con los métodos depurados de la época". La quinta se desarrolla en el siglo XVIII cuando los Borbones ocupan el trono de España, después de las guerras de sucesión en 1700, lo que supone, no sólo un cambio dinástico, sino también filosófico, ideológico y político que se refleja en el derecho. De ahí las reformas administrativas, económicas y jurídicas que se producen en este periodo que termina alrededor de 1810 cuando las provincias americanas van logrando progresivamente sus respectivas independencias.

\footnotetext{
${ }^{36}$ Rec. Indias, II.I.2.
} 
García-Gallo finaliza este trabajo señalando cuales han sido las etapas más estudiadas por los especialistas y llega a la conclusión de que son las iniciales por ser las más problemáticas y la final porque en ellas se sientan las bases de la estructura social y política de las nuevas repúblicas americanas, aunque advierte que: "los estudiosos a veces se han preocupado más de los aspectos políticos de las reformas que de los propiamente jurídicos".

\section{Epílogo}

En sus dos trabajos (el segundo, como ya he dicho, una especie de síntesis del primero), García-Gallo cumplió con dos de los requisitos esenciales de una correcta periodificación: dividir y caracterizar; aunque no con el de utilizar textos legislativos o doctrinales para señalar el principio y final de los periodos que tan importantes son, opino, cuando se trata de periodificar un sistema jurídico. Por ejemplo, la tercera etapa (que en "Génesis y desarrollo..." dura sólo dos años, pero que en "Las etapas..." acertadamente el autor une a la cuarta) la comienza con el sermón de Montesinos y la termina con el Memorial del bachiller Luis Sánchez al Consejo de Indias (acontecimientos ambos importantísimos en relación al tratamiento de los indios) pero no cuerpos legales o doctrinales. Yo hubiera utilizado las Leyes de Burgos (1512) como inicio de la etapa y la Copulata mandada a hacer por Ovando de 1569 (comienzo de las reformas ovandinas) como final de la mismo; y así en todos los periodos. Por otra parte, en ninguno de los dos trabajos García-Gallo fija los criterios con los que va a periodificar, aunque queda claro que tiene en cuenta criterios metajurídicos: políticos, económicos, religiosos, étnicos, etc. Quizás por eso, en "Génesis y desarrollo..." sólo habla de evolución; y en "Las etapas..." advierte sobre la dificultad de dividir en periodos la historia de un sistema jurídico tan complejo como el indiano. Así, solamente señala "hitos", en una periodificación que sin duda sigue la orientación histórica.

Por último, aunque reconozco que se trata de un tema polémico y espinoso y que depende de la visión que cada historiador tenga sobre la conquista de América por España, desde mi posición de hispanoamericana, me hubiese gustado que mi maestro tratara el tema desde un punto de vista más equilibrado y menos hispanista. No veo en el trabajo críticas severas al mal tratamiento de los indios, ni siquiera al real e indiscutido divorcio entre la ley y la realidad en la política que España siguió en las Indias.

Sólo me resta añadir para cerrar el círculo, retomando las palabras de Víctor Tau Anzoátegui (contenidas en el prólogo de este trabajo), que a García-Gallo debemos haber establecido criterios, reglas, orientación y estímulos para estudiar el derecho indiano, además de que fijó sus términos y limites, marcó sus horizontes, precisó su terminología y estableció sus bases metodológicas. Toda disciplina, dice Tau, necesita un orfebre mayor, y ese, en la nuestra, fue sin duda don Alfonso García-Gallo. 